\title{
Geographical parthenogenesis, genome size variation and pollen production in the arctic-alpine species Hieracium alpinum
}

\author{
Patrik Mráz $\cdot$ Jindřich Chrtek $\cdot$ Barbora Šingliarová
}

Received: 4 February 2009/Accepted: 11 May 2009/Published online: 22 July 2009

(c) Birkhäuser Verlag, Basel/Switzerland 2009

\begin{abstract}
Hieracium alpinum L. (Asteraceae) is an arcticalpine species distributed throughout Europe with both diploid and triploid cytotypes. We determined the ploidy levels of plants from 23 populations from Austria, Bosnia and Herzegovina, Finland, Italy, Norway, Romania, Slovakia, Switzerland and Ukraine. Data showed a nonoverlapping pattern of cytotype distribution: sexually reproducing diploids $(2 n=2 x=18)$ occur solely in the Eastern and Southern Carpathians, while apomictic
\end{abstract}

Responsible Editor: Christian Parisod.

Electronic supplementary material The online version of this article (doi:10.1007/s00035-009-0055-3) contains supplementary material, which is available to authorized users.

P. Mráz

Laboratoire d'Ecologie Alpine, UMR UJF-CNRS 5553,

Université Joseph Fourier, PO Box 53,

38041 Grenoble Cedex 9, France

Present Address:

P. Mráz $(\bowtie)$

Department of Biology, Unit of Ecology and Evolution, University of Fribourg, Chemin du Musée 10,

1700 Fribourg, Switzerland

e-mail: patrik.mraz@unifr.ch

J. Chrtek

Institute of Botany, Academy of Sciences of the Czech Republic, 25243 Průhonice, Czech Republic

J. Chrtek

Department of Botany, Faculty of Science,

Charles University in Prague, 12801 Prague 2, Czech Republic

B. Šingliarová

Institute of Botany, Slovak Academy of Sciences,

Dúbravská cesta 14, 84223 Bratislava, Slovakia triploids $(2 n=3 x=27)$ cover the rest of the range. Such clear-cut allopatry is rather rare in vascular plants with geographical parthenogenesis. Comparison of absolute genome size indicates genome downsizing (by on average $3.7 \%$ ) of haploid DNA amount in triploids relative to diploids. Genome size further correlated with longitude and latitude in the Alps, with decreasing absolute DNA content from west to east, and from south to north. While previously published data indicated complete male sterility of triploid plants, we found that plants from the Alps and Bosnia and Herzegovina commonly produced some pollen, whereas populations from the Western Carpathians and Scandinavia seemed to be almost completely pollen sterile. Scenarios about the evolution of geographical parthenogenesis in H. alpinum are discussed.

Résumé Hieracium alpinum L. (au sens strict) est une espèce arctique-alpine d'aire de répartition très large, comprenant les régions nordiques (le Groenland, l'Islande, l'Ecosse, la Scandinavie et le nord de la Russie) et les montagnes de l'Europe continentale (les Alpes, les Carpates, les Sudètes, les Vosges et le plateau de Vranica). Dans cette étude, nous avons compté le nombre chromosomique et estimé la ploïdie par cytométrie de flux de plantes provenant de 23 populations échantillonnées en Autriche, Bosnie et Herzégovine, Finlande, Italie, Norvège, Roumanie, Slovaquie, Suisse et Ukraine. Ces données et celles de la littérature montrent une nette séparation spatiale entre deux cytotypes différents: Les populations diploïdes sexuées sont réparties uniquement dans les Carpates orientales et occidentales (Roumanie et Ukraine), tandis que les populations triploïdes apomictiques occupent l'aire de répartition restante. Ce type d'allopatrie stricte est rare chez les plantes avec parthénogenèse géographique. En comparant la taille du génome haploïde (1Cx) des 
plantes triploïdes avec celui des plantes diploïdes, nous avons identifié une sensible réduction de taille du génome polyploïde (la divergence moyenne est 3.7\%). Parmi les plantes triploïdes, les individus du plateau de Vranica (Bosnie et Herzégovine) ont significativement moins d'ADN que les triploïdes provenant des Alpes ou des Carpates occidentales $(2 \mathrm{C}=10.28 \mathrm{pg}$ d'ADN contre 11.02 et $10.93 \mathrm{pg}$, respectivement). Une corrélation significative entre la taille du génome et la longitude et la latitude a été révélée dans les Alpes, avec des valeurs décroissantes d'ouest en est, et du sud vers le nord. Tandis que les données publiées indiquaient une stérilité mâle complète chez les triploïdes, nous avons trouvé des plantes triploïdes provenant des Alpes et du plateau de Vranica produisant du pollen, bien qu'en faible quantité et de taille hétérogène. Divers scénarios sur l'évolution de la parthénogénèse géographique chez $H$. alpinum sont discutés à la lumière de ces nouveaux résultats.

Keywords Apomixis - Chromosome numbers · Compositae · Flow cytometry - Genome downsizing . Male sterility $\cdot$ Polyploidy

\section{Introduction}

Sexual and asexual organisms belonging to closely related taxa often differ in spatial distribution. This geographical differentiation of sexuals and asexuals is called "geographical parthenogenesis" (Vandel 1928), and is one of the most challenging topics in evolutionary ecology. In plant species with geographical parthenogenesis, the apomictic (=asexual) lineages usually have larger ranges than their sexual relatives, are often shifted to higher latitudes or altitudes, and tend to occupy previously glaciated areas (Bierzychudek 1985; Asker and Jerling 1992). Several nonexclusive hypotheses have been proposed to explain the widespread distribution of apomictic groups. As almost all apomictic plants are polyploid, and many of them are of allopolyploid origin, multiple gene copies might provide greater physiological tolerance to apomicts than to their sexual diploid progenitors. Furthermore, uniparental reproduction is a safer pathway than sexual mating for the establishment of new populations during colonisation. Further potential mechanisms putatively involved in geographical parthenogenesis include biotic interactions or niche partitioning among closely related clones (Hörandl 2006).

The large polyploid genus Hieracium s. str.--hawkweed (excluding the genus/subgenus Pilosella) exhibits a geographical pattern of parthenogenesis. The great majority of karyologically analysed taxa are either tri- or tetraploid, reproduce asexually and occupy a large holarctic range
(Gustafsson 1946; Schuhwerk 1996). Conversely, sexual diploid taxa are rare and mostly confined to restricted ranges in southern parts of Europe (Merxmüller 1975; Vladimirov 2000; Castro et al. 2007; Chrtek et al. 2007). In Hieracium s.str., species typically contain only one ploidy level. One of the rare hawkweeds showing intraspecific variation in ploidy level and breeding system is H. alpinum.

Hieracium alpinum L. (s. str.) is an arctic-alpine species with two main areas of distribution: northern Europe (Scandinavia, Scotland, Iceland, Greenland, northwest Siberia and northern Ural) and high mountain ranges in Central Europe (Alps, Carpathians, Sudetes). Isolated populations were also recorded in the Harz (Germany), the Vosges (France), the Vranica planina (Bosnia and Herzegovina) and Central Italy (Gottschlich 1987; Bräutigam 1992). H. alpinum inhabits the alpine tundra and only rarely occurs in the subalpine belt. Published chromosome data on $H$. alpinum indicate the presence of at least two different ploidy levels: $2 n=3 x=27$ and $2 n=2 x=18$ (Table 1). There is only one tetraploid record $(2 n=$ $4 x=36$ ) from the Western Carpathians (Szeląg and Jankun 1997). Available data suggest that triploids are widely distributed while diploids occur only in the Carpathians (Table 1). However, ploidy levels in some regions, notably in the Alps have not yet been studied in sufficient detail to exclude the possibility that diploids also occur in this large mountain range, considered to be an important evolutionary centre and refugium of high mountain flora (e.g. Pawłowski 1970; Ozenda 1985; Schönswetter et al. 2005).

Diploid plants of $H$. alpinum are sexual and strictly outcrossing (Chrtek 1997; Mráz 2003). In contrast, triploid $H$. alpinum reproduces via agamospermy (apomixis), like other polyploid Hieracium taxa. Based on the embryological study of female meiosis, Skawińska (1963) determined a diplospory of Antennaria type in triploid H. alpinum: an unreduced embryo sac is formed from the mother cell through two mitotic divisions, with further parthenogenetic development into a mature embryo sac before the opening of flower heads. Hieracium s.str. polyploids are believed to be obligate apomicts, as no direct embryological or molecular evidence has provided evidence for sexual reproduction. Furthermore, male meiosis is partially or completely disturbed, mainly due to difficulties in chromosome pairing, resulting in a low production of pollen of heterogeneous size or in complete male sterility (Rosenberg 1927; Gentcheff and Gustafsson 1940; Aparicio 1994; Mráz et al. 2002). Only few data about the variation in pollen production and its geographic pattern are available for $H$. alpinum. Complete male sterility was observed in triploid plants from the Western Carpathians and Sudetes (Chrtek 1997), as well as from Scotland (Slade and Rich 2007). Only Rosenberg (1927) 
Table 1 List of published chromosome counts for Hieracium alpinum $\mathrm{L}$.

Data from the present study are shown in Fig. 1

${ }^{\text {a }}$ Number of chromosome records for particular geographical region (if two chromosome counts from the same locality were counted by different persons or counted on different plants later, they are considered as two different number records)

b Including $H$. augusti-bayeri (Zlatník) Chrtek

c Aneuploid chromosome number $(2 n=26)$

${ }^{\mathrm{d}}$ Published as " $H$. alpinum L. coll."

\begin{tabular}{|c|c|c|}
\hline Ploidy and region & $N^{\mathrm{a}}$ & Published source \\
\hline \multicolumn{3}{|l|}{ Diploid $(2 n=2 x=18)$} \\
\hline Eastern Carpathians & 17 & $\begin{array}{l}\text { Chrtek } 1997^{\text {b}} \text {; Mráz 2001, 2003; Mráz and Szeląg 2004; Mráz } \\
\text { et al. } 2005\end{array}$ \\
\hline Southern Carpathians & 4 & Mráz 2003; Mráz and Szeląg 2004 \\
\hline \multicolumn{3}{|l|}{ Triploid $(2 n=3 x=27)$} \\
\hline Alps & 2 & Huber and Baltisberger 1992; Schuhwerk and Lippert 1999 \\
\hline Greenland & 4 & $\begin{array}{l}\text { Böcher and Larsen 1950; Jorgensen et al. 1958; Gadella and } \\
\text { Kliphuis } 1971\end{array}$ \\
\hline Murmansk region & 1 & Sokolovskaya and Strelkova $1960^{\mathrm{c}}$ \\
\hline Scandinavia & 1 & Engelskjøn and Knaben $1971^{\mathrm{d}}$ \\
\hline Scotland & 2 & Stace et al. 1995 \\
\hline Sudetes & 7 & $\begin{array}{l}\text { Měsíček and Jarolímová 1992; Chrtek 1994; Chrtek and } \\
\text { Plačková } 2005\end{array}$ \\
\hline Ural & 2 & Lavrenko et al. 1988, 1989 \\
\hline Western Carpathians & 21 & $\begin{array}{l}\text { Skalińska 1959; Uhríková and Murín 1970; Murín and } \\
\text { Májovský 1992; Chrtek 1997; Mráz 2001; Štorchová et al. } \\
\text { 2002; Chrtek et al. } 2004\end{array}$ \\
\hline \multicolumn{3}{|c|}{ Tetraploid $(2 n=4 x=36)$} \\
\hline Western Carpathians & 1 & Szeląg and Jankun 1997 \\
\hline
\end{tabular}

reported a case of male meiosis, albeit highly disturbed, in triploid $H$. alpinum of unknown origin. The possibility of male meiosis deserves additional investigation as viable pollen can considerably enhance evolutionary potential by allowing gene flow between apomictic triploids and sexual diploids.

The main aims of our study are (1) to verify the geographic distribution patterns of diploids and triploids across Europe, (2) to look for intraspecific variation in genome size across the range of the cytotypes, and finally (3) to assess geographic variation in pollen production in triploid plants.

\section{Materials and methods}

Ploidy level and genome size estimation

Plants were collected at flowering time between 2003 and 2007 from their natural habitats (Appendix 1) and transplanted into experimental gardens in Košice (Slovakia) or Grenoble (France). Chromosome counts were made on four plants (Appendix 1) using root-tip meristems of pot-grown plants. Root tips were pre-treated with $0.5 \%$ solution of colchicine for $1.5-3 \mathrm{~h}$ at room temperature, fixed in a mixture of ethanol and glacial acetic acid (3:1) for at least $1 \mathrm{~h}$ and stored in $70 \%$ ethanol at $4^{\circ} \mathrm{C}$ until use. Hydrolysis was done in $1 \mathrm{~N} \mathrm{HCl}$ at $60^{\circ} \mathrm{C}$ for $7-10 \mathrm{~min}$. The "squash and smear" method replacing the glass covers with cellophane followed Murín (1960). Giemsa solution in phosphate buffer was used as a stain.
Nuclear DNA content was analysed for 56 plants (Appendix 1) in the Laboratory of Flow Cytometry at P.J. Šafárik University, Košice, using leaves of Zea mays CE$777(2 \mathrm{C}=5.43 \mathrm{pg})$ as internal reference standard (Lysák and Doležel 1998). Samples were prepared using a twostep procedure (Otto 1990; Doležel and Göhde 1995). Approximately $1 \mathrm{~cm}^{2}$ of leaf tissues of both the sample and the reference internal standard were chopped together for about $30 \mathrm{~s}$ in a Petri dish containing $1 \mathrm{ml}$ of ice-cold Otto I buffer $(0.1 \mathrm{M}$ citric acid monohydrate $+1 \mathrm{ml} 0.5 \%$ Tween 20 adjusted to $200 \mathrm{ml}$ and filtered through a $42 \mu \mathrm{m}$ filter). Filtration through $42 \mu \mathrm{m}$ nylon mesh was followed by centrifugation at $150 \mathrm{~g}$ for $5 \mathrm{~min}$. The supernatant was removed and $100 \mu \mathrm{l}$ of fresh Otto I buffer was added. The nuclei in the pellet were resuspended and incubated for $30 \mathrm{~min}$ at room temperature. DNA was stained with $1 \mathrm{ml}$ of modified Otto II buffer $(0.4 \mathrm{M}$ disodium hydrogenphosphate dodecahydrate) including $50 \mu \mathrm{l}$ of propidium iodid (PI), $50 \mu \mathrm{l}$ ribonuclease (A R5000, Sigma), and $2 \mu \mathrm{l}$ mercaptoethanol.

Flow cytometry was carried out with a FACSCalibur instrument (Becton Dickinson, USA) equipped with an argon-ion laser exciting at $488 \mathrm{~nm}$. For comparison, the exact position of peaks of previously counted di-, tri- and tetraploid Hieracium taxa relative to the peak of the internal standard was measured (Chrtek et al. 2007). Coefficients of variation $(\mathrm{CV})$ of the peaks of internal standard adjusted at channel 100 ranged from 3.5 to $6.9 \%$, with an average value of $5.4 \%$, and $\mathrm{CV}$ of peaks of measured samples varied between 2.9 and $5.1 \%$, with an average value of $3.9 \%$. Genome size was determined in at 
least three independent runs per plant, and the mean was used. Measurements differing by more than $2 \%$ were discarded, and the sample was re-analysed.

Mean genome size of each population (=locality) was used in data analysis. Differences in mean monoploid genome size $(1 \mathrm{Cx})$ were tested by Tukey HSD test (1) between all populations comprising at least three individuals, and (2) between four different regions (Alps, Western Carpathians, Southern Carpathians and Vranica planina). Two-sample $t$ test with Welch approximation (due to unequal variances) was used to test the differences in mean monoploid genome size (1Cx) between diploid and triploid plants. Correlations between the genome size and the geographical position of populations (altitude, latitude and longitude) in the Alps were tested by Spearman rank tests.
All tests were done using the basic packages of R software (R Development Core Team 2006).

Pollen production

Pollen measurements were carried out on herbarium samples collected as vouchers for a phylogeographic study of $H$. alpinum (Appendix 2). Five flowers per plant (both inner and outer flowers) in the stage before anthesis were broken up with tweezers to release the pollen from the anthers. Pollen was stained by Alexander's stain (Alexander 1969). The staining pattern proved unsuitable to assess pollen viability because some clearly deformed pollen grains were stained as "viable" (red cytoplasm and green cell wall) while many pollen grains of regular shape and
Fig. 1 Distribution of karyologically and/or flow cytometrically analysed populations of Hieracium alpinum $\mathrm{L}$. Total range of the species is marked by grey shading (a Europe, b Ural and Northern Russia, c Greenland). Symbols used: filled circlelopen circle diploid populations (published/new data), filled trianglelopen triangle triploid populations (published/new data)

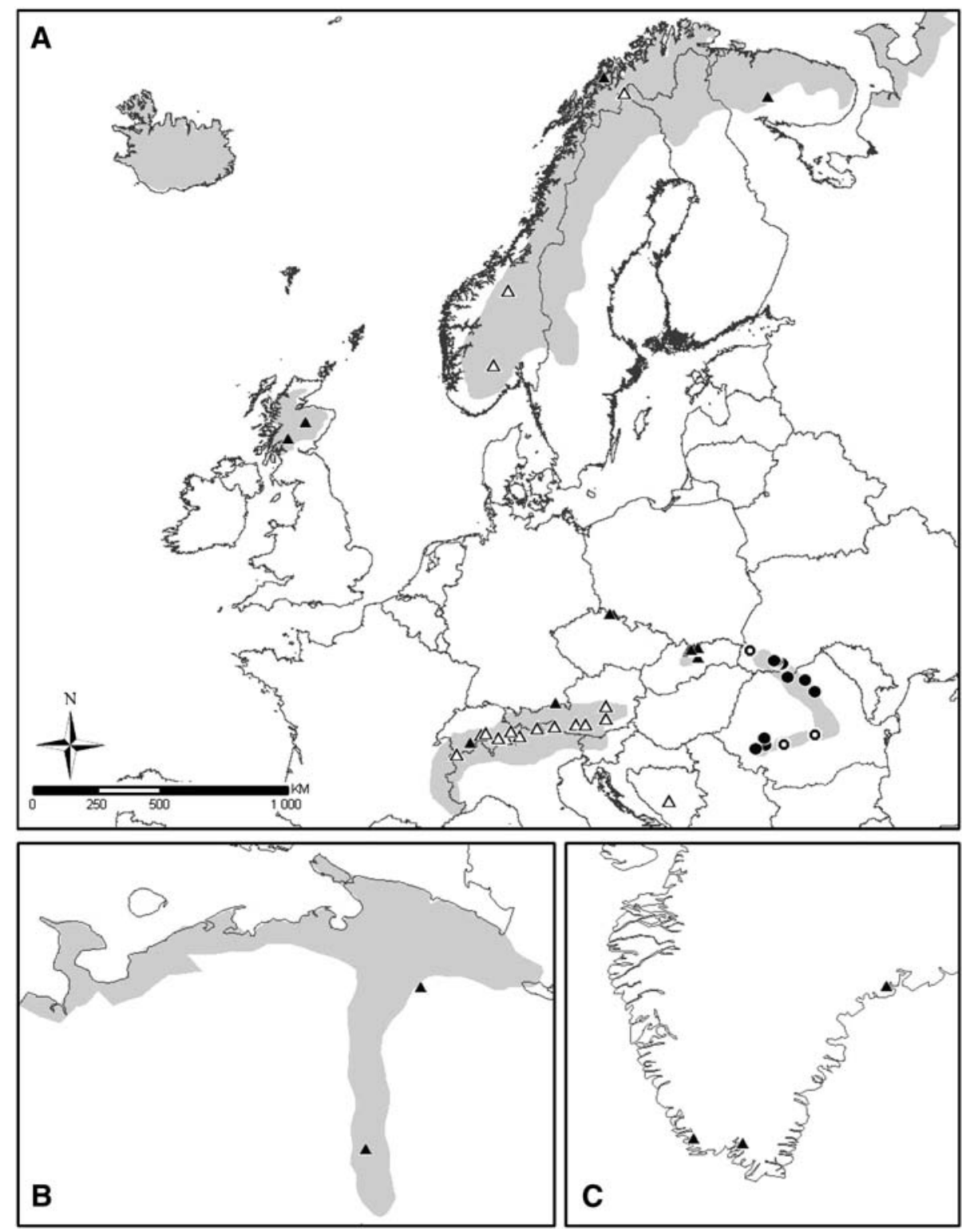


Table 2 Absolute genome size estimation in diploid and triploid populations of Hieracium alpinum L.

\begin{tabular}{|c|c|c|c|c|c|}
\hline Ploidy level and population ${ }^{\mathrm{a}}$ & $N$ & $\begin{array}{l}\text { Mean 2C-value } \\
\text { (pg DNA) }\end{array}$ & $\begin{array}{l}\text { 2C value range } \\
\text { (pg DNA) }\end{array}$ & $\begin{array}{l}\text { Variation } \\
\max / \min (\%)\end{array}$ & Mean $1 C x$-value ${ }^{b}$ \\
\hline \multicolumn{6}{|l|}{ Diploid populations $(2 x)$} \\
\hline ROM, Nedea & 3 & $7.57 \pm 0.03$ & $7.55-7.61$ & 0.7 & $3.79 \mathrm{a}$ \\
\hline ROM, Bucegi & 4 & $7.56 \pm 0.07$ & $7.45-7.61$ & 2.1 & $3.78 \mathrm{a}$ \\
\hline \multicolumn{6}{|l|}{ Triploid populations $(3 x)$} \\
\hline AUT, Turracher Höhe & 1 & 11.01 & & & 3.67 \\
\hline AUT, Reißeckhütte & 2 & $10.88 \pm 0.08$ & $10.82-10.93$ & 1.0 & 3.62 \\
\hline AUT, Leobnerhütte & 3 & $11.01 \pm 0.02$ & $10.99-11.02$ & 0.2 & $3.67 \mathrm{~b}, \mathrm{~d}$ \\
\hline AUT, Stallersattel & 1 & 10.89 & & & 3.63 \\
\hline AUT, Altes Almhaus & 1 & 10.96 & & & 3.65 \\
\hline BIH, Vranica & 3 & $10.28 \pm 0.06$ & $10.22-10.33$ & 1.1 & $3.43 \mathrm{c}$ \\
\hline CHE, Julier pass & 1 & 11.23 & & & 3.74 \\
\hline CHE, Passo dello Spluga & 2 & $11.04 \pm 0.09$ & $10.97-11.10$ & 1.2 & 3.68 \\
\hline CHE, Furkapass & 1 & 11.10 & & & 3.70 \\
\hline CHE, Oberalppass & 1 & 11.02 & & & 3.67 \\
\hline CHE, Grand St. Bernard & 4 & $11.07 \pm 0.09$ & $10.95-11.14$ & 1.7 & $3.69 b$ \\
\hline ITA, Passo di Giovo & 2 & $11.09 \pm 0.00$ & $11.09-11.10$ & 0.2 & 3.70 \\
\hline ITA, Passo di Pennes & 2 & $10.89 \pm 0.17$ & $10.77-11.01$ & 2.2 & 3.63 \\
\hline ITA, Passo dello Stelvio & 3 & $11.11 \pm 0.09$ & $11.01-11.23$ & 2.0 & $3.70 \mathrm{~b}$ \\
\hline SVK, Furkotská dolina & 2 & $11.01 \pm 0.07$ & $10.96-11.06$ & 0.9 & 3.67 \\
\hline SVK, Baranec & 4 & $10.89 \pm 0.04$ & $10.85-10.94$ & 0.8 & $3.63 \mathrm{~d}$ \\
\hline
\end{tabular}

${ }^{a}$ Country codes: AUT Austria, BIH Bosnia and Herzegovina, CHE Switzerland, ITA Italy, ROM Romania, SVK Slovakia

b $1 \mathrm{CX}$-value (mean monoploid genome size) is the mean 2C-value divided by ploidy level. Multiple comparison test (Tukey HSD, at $P<0.05$ ) was performed on $1 \mathrm{Cx}$ values for populations comprising at least three analysed plants. Mean monoploid values (1Cx) sharing the same letter are not significantly different

size were not stained at all. Therefore, pollen production was only estimated semi-quantitatively on a six-point scale ranging from "-" no pollen, or only sporopolenin remnants present, to " +++++ " pollen very abundant, as in the diploid cytotype.

\section{Results}

Geographical pattern of the cytotype distribution

Diploids were found only in the Eastern and Southern Carpathians (Romania and Ukraine), while a triploid level was ascertained for plants originating from the Western Carpathians, the Alps, Scandinavia and the Vranica planina (Bosnia and Herzegovina). For the last region, as well as for the accessions from Austria, Italy and Finland, these are the first DNA-ploidy level estimations reported. The cytogeographic pattern based on present and published records clearly shows a spatial split of diploid populations and triploid populations. The sexually reproducing diploid cytotype occurs exclusively in the Eastern and Southern Carpathians (Romania and Ukraine), while apomictic triploids occupy the remaining range of the species (Fig. 1; Table 1).
Genome size variation

Absolute genome size was quantified for 40 plants of $H$. alpinum originating from the diploid (the Southern Carpathians) and triploid range (the Alps, the Vranica planina and the Western Carpathians). Averaged absolute genome size values (2C) for each population, as well as ranges for $2 \mathrm{C}$ and $1 \mathrm{Cx}$ (monoploid genome size) are given in Table 2 . The individual $2 \mathrm{C}$ values within diploid cytotype range from 7.45 to $7.61 \mathrm{pg}$ DNA (2.1\% divergence within diploid ploidy level), with mean value of $7.56 \mathrm{pg}$. Between-individual variation in $2 \mathrm{C}$ value within triploid ploidy level was higher compared to diploid plants, and ranged from 10.22 to $11.23 \mathrm{pg}$, representing almost $10 \%$ divergence. This differentiation within triploids, however, arises primarily from low DNA content found in all analysed plants from the geographically isolated Vranica population. Because triploid plants from the Vranica planina showed considerably lower DNA content than triploids from the Alps and the Western Carpathians in first repetitive analyses, these accessions were re-analysed (again with three replications per plant) 1 month later, but the initial result was confirmed. Average divergence in mean $2 \mathrm{C}$ values between the Vranica population and the four tested triploid 
Table 3 Comparison of the absolute genome size of Hieracium alpinum L. belonging to different cytotypes and geographical origins

\begin{tabular}{lrlccc}
\hline Region (ploidy level) & $N^{\mathrm{a}}$ & $\begin{array}{l}\text { Mean 2C } \\
\text { value (pg DNA) }\end{array}$ & $\begin{array}{l}\text { 2C value range } \\
\text { (pg DNA) }\end{array}$ & $\begin{array}{l}\text { Mean } 1 \mathrm{~min}-\text { max } \\
\text { value (pg DNA) }\end{array}$ \\
\hline S Carpathians (2x) & 7 & 7.56 & $7.45-7.61$ & 2.1 & $3.78 \mathrm{a}$ \\
Alps (3x) & 23 & 11.02 & $10.77-11.23$ & 4.3 & $3.67 \mathrm{~b}$ \\
W Carpathians (3x) & 6 & 10.93 & $10.85-11.06$ & 1.9 & $3.64 \mathrm{~b}$ \\
Vranica, Balkan (3x) & 3 & 10.28 & $10.22-10.33$ & 1.1 & $3.43 \mathrm{c}$ \\
\hline
\end{tabular}

${ }^{\text {a }}$ Number of analysed plants per region

b Mean monoploid values $(1 \mathrm{Cx})$ sharing the same letter are not significantly different (Tukey HSD test, $P<0.05$ )

populations is $7.2 \%$. The maximal inter-individual divergence within one mountain range was recorded among the plants from the Alps (4.3\%).

Mean monoploid genome size (1Cx) differed significantly between the Vranica and all other tested populations, as well as between diploid populations and all tested triploid populations (Tukey HSD tests, $P<0.05$ ). No significant differences were recorded between triploid populations from the Alps and the Western Carpathians, with exception of the Baranec population in the Western Carpathians (Table 2). When data obtained from individual plants were grouped by geographical origin, statistically significant differences were found between: (1) the triploids from the Alps/Western Carpathians and the Vranica planina, (2) the triploids from the Alps/Western Carpathians and the diploids from the Southern Carpathians, and (3) the triploid plants from the Vranica planina and the diploids from the Southern Carpathians (Table 3). A significant monoploid genome downsizing was recorded in diploid plants when compared to all triploids with mean divergence of $3.7 \%$ (Welch two sample $t$ test, $t=7.93$, $d f=27.5, P<0.001)$. When plants from the Vranica planina were excluded from the analysis the divergence was smaller $(3.1 \%)$, but still highly significant (two sample $t$ test, $t=9.23, d f=35, P<0.001)$.

Significant negative correlations between genome size and latitude and longitude were revealed for accessions from the Alps $\left(r_{\mathrm{s}}=-0.629, P=0.0214\right.$, and $r_{\mathrm{s}}=$ $-0.576, P=0.0395$, respectively). No significant correlation was found between genome size and altitude $\left(r_{\mathrm{s}}=0.517, P=0.0719\right)$.

Variation in pollen production

The only plants included in our observations that originated from the range occupied solely by diploids are those from the Horhany ridge (Ukrainian Eastern Carpathians). In this population, we found a high amount of pollen of homogeneous size (Fig. 2a, b). Most of the triploid plants did not produce pollen at all $(85 \%$ of all triploids studied, cf. Table 4; Fig. 2c). However, some pollen production was observed in 10 plants from the Alps (27\% of plants studied from this range), in both plants analysed from the Vranica planina and in one plant from the Western Carpathians $(2.6 \%)$ and Scandinavia $(6.2 \%)$ (Table 4$)$. These malefertile triploids produced only a small amount of pollen in comparison with diploids and this pollen was always of heterogeneous size (Fig. 2d). Moreover, the pollen of triploid plants frequently showed poorly developed exine structure.

\section{Discussion}

Cytogeographic pattern and geographical parthenogenesis

Hieracium alpinum can be considered a clear-cut example of geographical parthenogenesis: diploids occupy only a restricted area at the low latitude range margin, whereas apomictic triploids cover a much larger area, including polar latitudes and previously extensively glaciated areas like the Alps and northern Europe (Fig. 1). A surprising pattern is the completely non-overlapping distribution of sexual and asexual plants. The recent closest localities of diploid (Mount Pikuï in the Eastern Carpathians, Ukraine) and triploid (the Belianske Tatry mountains in the Western Carpathians, Slovakia) cytotypes are separated by c. $200 \mathrm{~km}$. In other species showing geographical parthenogenesis, both reproduction modes co-occur, at least in some areas (Asker and Jerling 1992; Hörandl 2006). Assuming a high colonisation potential of triploid $H$. alpinum (based on its present range), it is interesting that no triploid plant (either of in situ origin or as immigrant from triploid range) have been detected in the diploid range so far. This might suggest that (1) recent diploids are not able to produce stable triploid progeny, or (2) effective dispersal of triploids into the diploid range is prevented, or (3) there is some selection mechanism precluding their successful establishment. The first two hypotheses seem plausible. Indeed, the production of unreduced gametes, considered the most important pathway to polyploidy (Ramsey and 
Fig. 2 Pollen in Hieracium alpinum L. a anthers with a lot of pollen in diploid plant, b homogeneous sized pollen in diploid plant (both plants from the population Alp-56, Ukraine Mount Mala Syvulya), c anthers without pollen in triploid plant (population Alp-26, Austria, Sölkpass), some remnants of degenerated tapetum layer are visible, $\mathbf{d}$ few pollen grains of heterogenous size in the anther of triploid plant (population Alp-23, Austria, Mount Seekareck). Scale bar $=100 \mu \mathrm{m}(\mathbf{a}$ and $\mathbf{c})$, $50 \mu \mathrm{m}(\mathbf{b}$ and $\mathbf{d})$
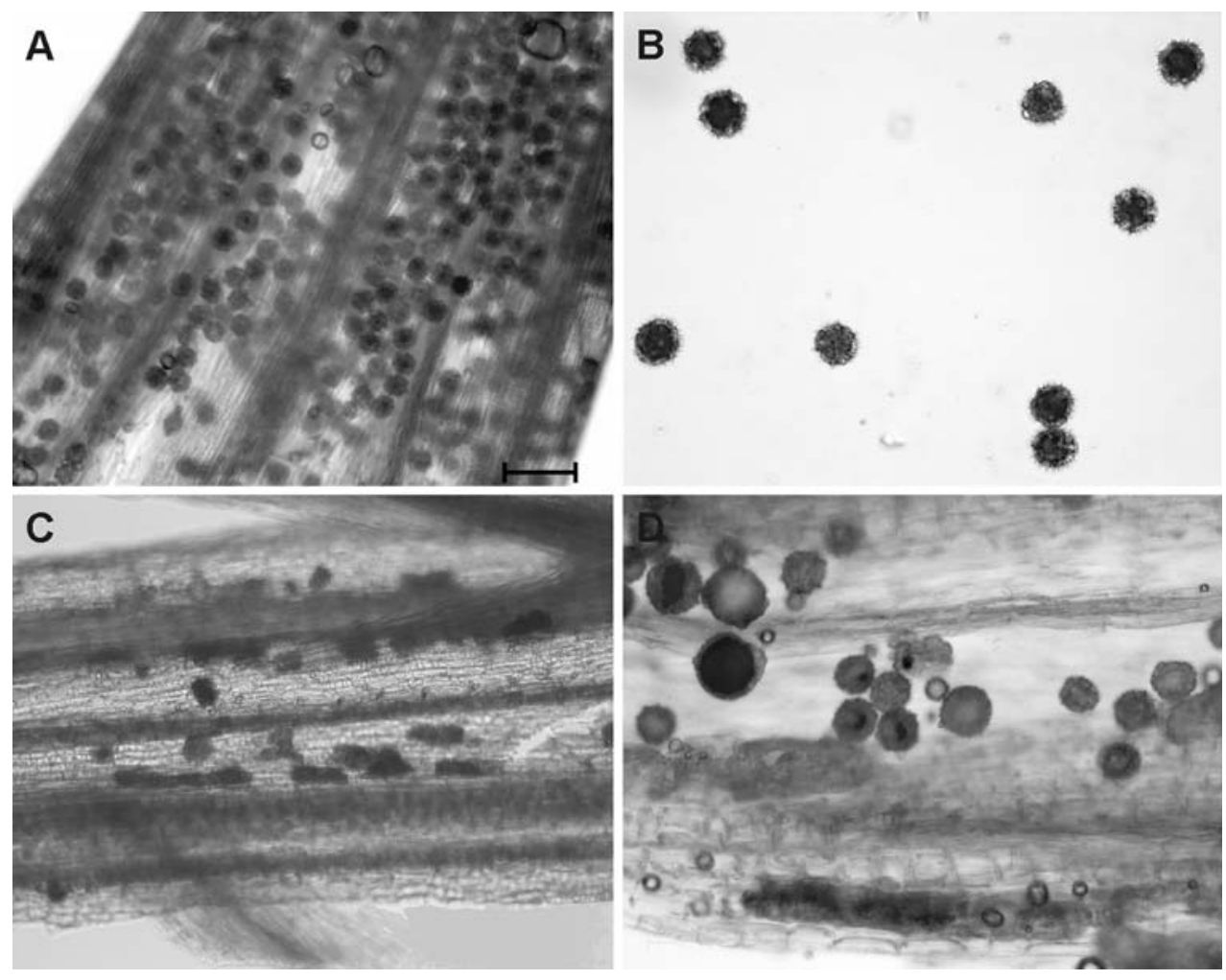

Table 4 Semi-quantitative estimation of pollen production in Hieracium alpinum $\mathrm{L}$.

${ }^{\text {a }}$ Total number of plants analysed

b Relative pollen abundance from "-" (no pollen) to " $+++++"$ (pollen very abundant as in diploid cytotype) for each of the plants analysed

\begin{tabular}{lrl}
\hline Region/population code (Appendix 2) & $N^{\mathrm{a}}$ & Pollen quantity $^{\mathrm{b}}$ \\
\hline Alps $(3 x)$ & & \\
Alp-2, 4, 11, 12, 15, 18, 20, 22, 24, 25 & - (all plants) \\
Alp-5 & 2 &,-++ \\
Alp-14 & 2 &,-+ \\
Alp-16 & 1 & ++++ \\
Alp-17 & 3 &,,-++++ \\
Alp-21 & 2 &,-+ \\
Alp-23 & 4 &,,,-+++++++ \\
Alp-26 & 3 &,,--+++ \\
Eastern Carpathians $(2 x)$ & & \\
Alp-56 & 2 & $+++++($ both plants) \\
Scandinavia $(3 x)$ & & \\
Alp-93, 94, 95, 96, 97, 98, 101, 103 & 13 & $-($ all plants $)$ \\
Alp-102 & 4 &,,,---++ \\
Yamal Peninsula $(3 x)$ & & \\
Alp-Yam & 2 & $-($ both plants) \\
Vranica $(3 x)$ & & \\
Alp-87 & 2 &,+++++ \\
Western Carpathians $(3 x)$ & &,,--+++ \\
Alp-32, 34, 35, 36, 37, 38, 39, 40, 41, 45, 46, 47, 48 & 37 & \\
Alp-44 & 3 & \\
\hline
\end{tabular}

Schemske 1998), seems to be rare in diploid Hieracium taxa including $H$. alpinum. No larger pollen grains indicating larger genome content were observed during a detailed study of pollen production and size in diploid hawkweeds (Kovalčiková 2004). Furthermore, long-distance dispersal is stochastic and usually involves singular 
Fig. 3 Distribution of triploid apomictic populations of Hieracium alpinum L. where pollen production was examined (a Scandinavia, b the Western Carpathians, $\mathbf{c}$ the Alps and Vranica planina). Symbol used: "filled circle" at least one plant from analysed population produced some pollen; "open circle" none of analysed plants from population produced pollen (for details see "Material and methods", supplementary material Appendix 2 and Table 4). The remnant locality from the Yamal Peninsula (NE Russia) was not included in the map

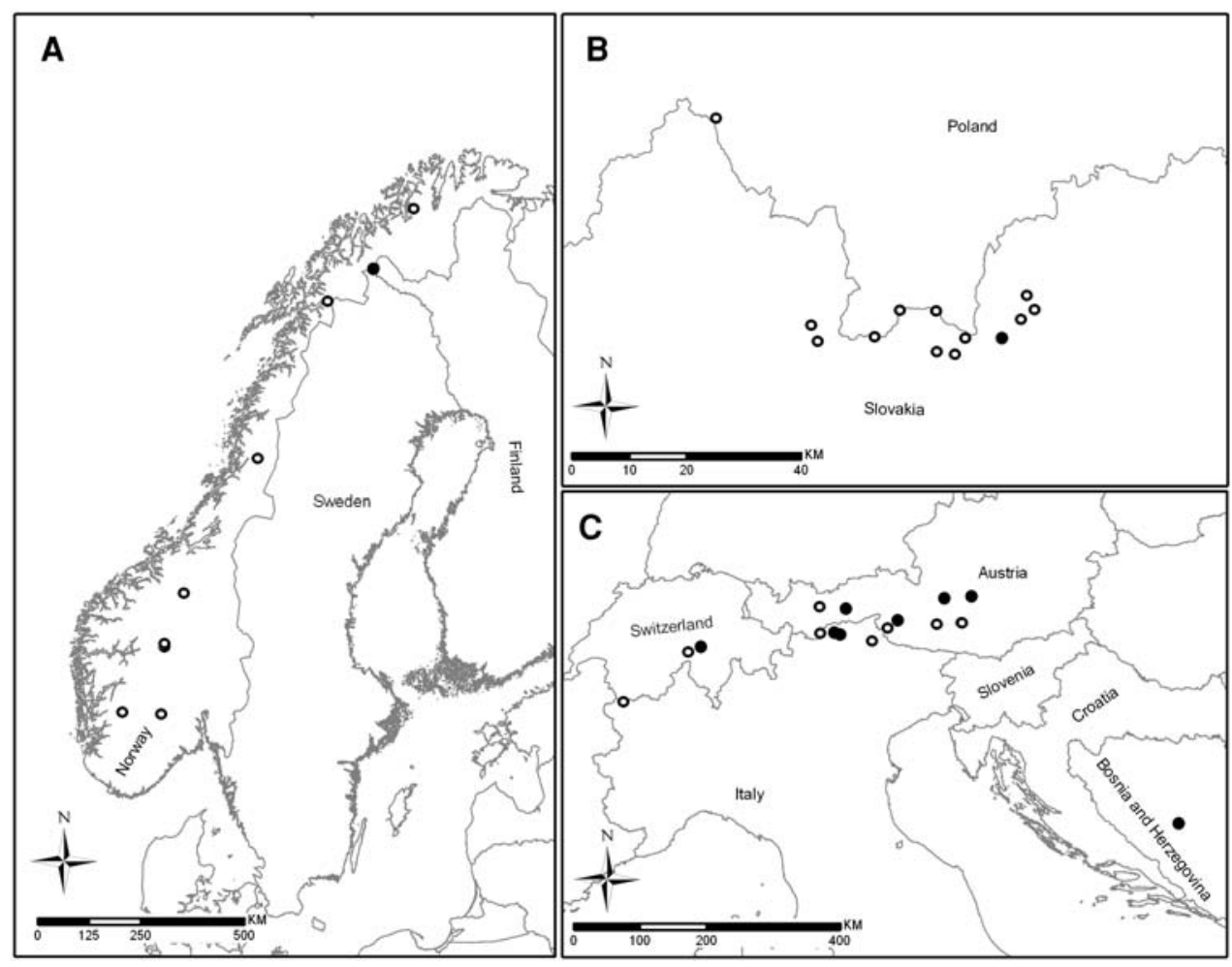

events only (Nathan 2006, but see Alsos et al. 2007), maybe restricting the invasion of the diploid range by triploids. Nevertheless, the strict allopatry of $H$. alpinum cytotypes would probably be better explained by restricted effective dispersal involving adaptive mechanisms that further prevent recruitment. It has been hypothesised that sexual lineages are better competitors than asexual ones because sexual recombination can sustain selection, while apomicts might be more successful on disturbed places or extreme types of habitats with fewer biotic interactions (Asker and Jerling 1992, but see de Kovel and de Jong 2001). In H. alpinum, however, there are no striking differences between the habitats occupied by both cytotypes in their respective ranges. Diploids and triploids both grow in open as well as in more dense vegetation communities, suggesting that selection does not play a key role in maintaining cytotype separation in H. alpinum.

Results from a large-scale molecular screening of $H$. alpinum populations (Mráz et al., unpublished data) indicate a polytopic origin of triploid apomicts and only a loose genetic relatedness with the recent diploids. Together with the disjunct ranges of diploids and triploids, and the occurrence of many closely related microspecies within the triploid range, this suggests that triploid plants of H. alpinum are probably remnants of extinct diploid lineages rather than descendants of contemporary diploid populations.
Genome size variation and its geographical pattern

In our study, we confirmed a general trend of genome downsizing in polyploids with respect to their diploid progenitors (Leitch and Bennett 2004). This contrasts with the closely related genus Pilosella, where downsizing was not apparent in triploids, but only at higher ploidy levels (Suda et al. 2007). Several mechanisms may lead to genome size reduction in polyploids: (1) unequal homologous recombination, (2) elimination of specific DNA sequences (including sequences in low- and high copy number from both coding and non-coding regions), and (3) change in transposons activity (Leitch and Bennett 2004).

In $H$. alpinum, a significant genome size reduction (in average ca 7\%) was detected in the isolated population of the Vranica planina. Because the exact chromosome numbers of plants from the Vranica population were not determined, we could not exclude the possibility that this intraspecific variation in DNA content is due to aneuploidy. In fact, aneuploidy $(2 n=26)$ was previously reported in individuals of $H$. alpinum from the Murmansk region (Sokolovskaya and Strelkova 1960), but aneuploidy is extremely rare in the genus Hieracium (Schuhwerk 1996). The loss of DNA observed in H. alpinum from the isolated population of Vranica planina could be attributed to other phenomena like a selection for smaller genome size. Indeed, Knight and Beaulieu 
(2008) showed a correlation between plant genome size and some traits involved in evapotranspiration, such as length of the guard cells, epidermal cell area and stomatal density. Taking into account the particular climatic conditions at Vranica planina (the southernmost known population of $H$. alpinum), we cannot exclude an adaptive scenario in this case. An alternative explanation for genome size reduction in Balkan plants might be the different evolutionary origin, because the Vranica population is genetically distinct from the other triploid populations (Mráz et al., unpublished data).

With the exception of the Vranica plants, betweenindividual or inter-population (or interregional) variation in genome size of $H$. alpinum was moderate. The maximal divergence between two triploid plants (excluding the Vranica population) was $4.3 \%$. The plants from the Alps were more variable (expressed as min and max range of 1Cx) than the plants from the Western Carpathians, in concordance with higher genetic variation found in triploid plants from the former region (Mráz et al. unpublished data). However, we analysed more plants from the larger area of the Alps than from the Carpathians, and possible sampling bias should be taken into consideration. Significant negative correlations between genome size of triploid $H$. alpinum and latitude and longitude were recorded in the Alps. Clinal variation in genome size remains a contentious issue. It has been tentatively proposed to be an adaptation to local climatic conditions (e.g. Temsch and Greilhuber 2001; Schmuths et al. 2004; Bancheva and Greilhuber 2006). Therefore we also examined whether some relationship could be found between the genome size and mean annual precipitation and temperature as derived from the WorldClim model (Hijmans et al. 2005). We found no correlation (data not shown), but the results should be interpreted with caution because the WorldClim model is spatially very coarse.

Variation in pollen production

A large quantity of pollen of homogeneous size is characteristic for diploid H. alpinum (Chrtek 1997; Mráz et al. 2002; Kovalčiková 2004; Chrtek et al. 2006; Slade and Rich 2007). In contrast, most plants from the triploid range did not produce pollen at all (Table 4). This finding concurs with those of Chrtek (1997), Kovalčiková (2004) and Slade and Rich (2007) who observed no pollen in triploid cytotype in the Western Carpathians and Scotland. However, in the present study, we detected some level of pollen production in triploids from the Alps, the Vranica planina, and very rarely from the Western Carpathians and Scandinavia (Table 4, Fig. 3). The most noteworthy is the high proportion $(27 \%)$ of partially male fertile plants from the Alps, and mainly from the eastern part. From present and published data (see above), it is obvious that triploids in northern latitudes (Scandinavia, Scotland, Sudetes, Yamal Peninsula, the Western Carpathians) are mostly male sterile, while triploids from southerly situated Alps or the Vranica planina can more frequently produce some pollen. This indicates that triploid $H$. alpinum is not completely male sterile, as previously suggested. Intraspecific polymorphism in pollen production has also been reported in other polyploid Hieracium taxa (Mráz 2002; Kovalčiková 2004; Slade and Rich 2007; Rich et al. 2008). Interestingly, in some cases we recorded variation in pollen production within one flower head, or even within one flower (some anthers with pollen, some anthers completely empty). Similarly, variation in pollen production within the same head or the same flower was observed in triploid $H$. villosum (Urbanska 1991). Slade and Rich (2007) reported that cultivated plants of some polyploid taxa produced pollen more often than wild plants, suggesting that environmental factors might have an influence on pollen production in apomictic Hieracium species.

Pollen production is considered as a significant reproductive cost in plants. For instance, Meirmans et al. (2006) found that male-sterile apomictic dandelions (Taraxacum sect. Ruderalia) produce more flower heads per plant, and thus more seeds, than pollen-producing apomicts. Pollen production thus seems implausible in apomictic $H$. alpinum, because successful production of seeds is completely independent of pollination and fertilisation. Maynard Smith (1978) proposed a non-adaptive hypothesis for the retention of male function, suggesting that apomicts producing pollen are phylogenetically too recent to have accumulated enough mutations for male sterility. Alternatively, male apomicts could be advantageous if they are able to mate with diploids, thus creating new clones or reducing the fitness of co-occurring sexual competitors (Mogie 1992). Although we have no indication of present-day sympatric occurrence of diploids and triploids, such a situation might have been possible in the past, when new triploid clones arose within diploid populations.

Acknowledgments Authors are thankful to colleagues and friends, mentioned in Appendix 2, for their kind help with sampling and/or cotravelling, to Tim Rich and Martin Henery for English revision of manuscript and Róbert Šuvada for map preparation and providing of WorldClim data. We greatly appreciate the suggestions of two anonymous reviewers on the first draft of manuscript. This study was performed as a part of Marie Curie Intra European fellowship (no. 10961, to PM). Sampling in summer 2005 (before official starting of this European project) was supported from the grant of The Research and Development Support Agency of Slovak Republic (no. 006404), The Czech Science Foundation (grant no. 206/05/0657, to JC) and Ministry of Education, Youth and Sports of the Czech Republic (grant no 0021620828 , to JC). 


\section{Appendix}

Appendix 1. New chromosome counts and estimations of DNA-ploidy level in Hieracium alpinum s.str.

Appendix 2. Geographic origin of the plants of Hieracium alpinum L. used for pollen observations.

This Appendix can be downloaded freely from http://www.birkhauser.ch/BH.

\section{References}

Alexander MP (1969) Differential staining of aborted and nonaborted pollen. Stain Technol 44:117-122

Alsos IG, Eidesen PB, Ehrich D, Skrede I, Westergaard K, Jacobsen GH, Landvik JY, Taberlet P, Brochmann C (2007) Frequent long-distance plant colonization in the changing Arctic. Science 316:1606-1609

Aparicio A (1994) Karyological studies in Hieracium baeticum (Asteraceae) from the "Parque Natural de la Sierra de Grazalema" (Southern Spain). Fl Medit 4:25-34

Asker SE, Jerling L (1992) Apomixis in plants. CRC Press, Boca Raton

Bancheva S, Greilhuber J (2006) Genome size in Bulgarian Centaurea s.l. (Asteraceae). Plant Syst Evol 257:95-117

Bierzychudek P (1985) Pattern in plant parthenogenesis. Experientia 41:1255-1264

Böcher TW, Larsen K (1950) Chromosome numbers of some arctic or boreal flowering plants. Medd Grønl 147:28

Bräutigam S (1992) Hieracium L. In: Meusel H, Jäger EJ (Eds) Vergleichende Chorologie der zentraleuropäischen Flora 3. Gustav Fischer, Jena etc., pp 325-333, 550-560

Castro M, Mateo G, Rossello JA (2007) Chromosome numbers in Hieracium and Pilosella species (Asteraceae) from the Iberian Peninsula and the Balearic Islands. Bot J Linn Soc 153:311-320

Chrtek J (1994) Chromosome numbers in selected Hieracium species in the Krkonoše Mts (the West Sudeten). Folia Geobot Phytotax 29:91-100

Chrtek J Jr (1997) Taxonomy of the Hieracium alpinum group in the Sudeten Mts., the West and the Ukrainian East Carpathians. Folia Geobot Phytotax 32:69-97

Chrtek J, Plačková I (2005) Genetic variation in Hieracium alpinum (Asteraceae) in the Krkonoše Mts (West Sudeten Mts, Czech Republic). Biologia (Bratislava) 60:387-391

Chrtek J Jr, Mráz P, Severa M (2004) Chromosome numbers in selected species of Hieracium s.str. (Hieracium subgen. Hieracium) in the Western Carpathians. Preslia 76:119-139

Chrtek J Jr, Mráz P, Sennikov AN (2006) Hieracium $\times$ grofae-a rediscovered diploid hybrid from the Ukrainian Carpathians. Biologia (Bratislava) 61:365-373

Chrtek J, Mráz P, Zahradníček J, Mateo G, Szeląg Z (2007) Chromosome numbers and DNA-ploidy levels of selected species of Hieracium s.str. (Asteraceae). Folia Geobot 42:411430

De Kovel CGF, De Jong G (2001) The effect of intra-specific competition on seedlings of sexual and apomictic Taraxacum officinale. Oikos 95:25-30

Doležel J, Göhde W (1995) Sex determination in dioecious plants Melandrium album and M. rubrum using high-resolution flow cytometry. Cytometry 19:103-106

Engelskjøn T, Knaben G (1971) Chromosome numbers of Scandinavian arctic-alpine plants species III. Acta Boreal A 28:1-30
Gadella TWJ, Kliphuis E (1971) [Report on H. alpinum]. In: Löve Á (Ed) IOPB Chromosome number reports, Taxon 20:158

Gentcheff G, Gustafsson $\AA$ (1940) The balance system of meiosis in Hieracium. Hereditas 26:209-248

Gottschlich G (1987) Hieracium L. In: Wagenitz G (Ed) Hegi Illustrierte Flora von Mitteleuropa 6/2, edn 2. P. Parey, Berlin et Hamburg, 1182-1351

Gustafsson A (1946) Apomixis in higher plants. Part I. The mechanism of apomixis. Acta Univ Lund 42:1-67

Hijmans RJ, Cameron SE, Parra JL, Jones PG, Jarvis A (2005) Very high resolution interpolated climate surface for global and land areas. Int J Clim 25:1965-1978

Hörandl E (2006) The complex causality of geographical parthenogenesis. New Phytol 171:525-535

Huber W, Baltisberger M (1992) IOPB chromosome data 4. Newsl IOPB 18(19):6-8

Jorgensen CA et al (1958) The flowering plants of Greenland. A taxonomical and cytological survey. Dansk Vidensk Selsk Biol Skr 9:1-172

Knight CA, Beaulieu JM (2008) Genome size scaling through phenotype space. Ann Bot 101:759-766

Kovalčiková K (2004) Veľkosť peľu v blízko príbuzných rodoch Hieracium, Pilosella a Stenotheca (Asteraceae) [Pollen size in closely related genera Hieracium, Pilosella and Stenotheca (Asteraceae)]. Master thesis, Institute of Biology and Ecology, P.J. Šafárik University, Košice

Lavrenko AN, Serditov NP, Ulle ZG (1988) Chromosome numbers in some species of Asparagaceae, Asteraceae and Ranunculaceae from the North Urals (Komi ASSR). Bot Zhurn 73:605-607

Lavrenko AN, Serditov NP, Ulle ZG (1989) Chromosome numbers in some species of flowering plants of the Urals (the Komi Autonomous Soviet Socialist Republic). Bot Zhurn 74:1059-1062

Leitch IJ, Bennett MD (2004) Genome downsizing in polyploid plants. Biol J Linn Soc 82:651-663

Lysák MA, Doležel J (1998) Estimation of nuclear DNA content in Sesleria (Poaceae). Caryologia 51:123-132

Maynard Smith J (1978) The evolution of sex. Cambridge University Press, Cambridge

Meirmans PG, den Nijs JCM, van Tienderen PH (2006) Male sterility in triploid dandelions: asexual females vs asexual hermaphrodites. Heredity $96: 45-52$

Merxmüller H (1975) Diploide Hieracien. Anal Inst Bot Cavanilles 32:189-196

Měsíček J, Jarolímová V (1992) List of chromosome numbers of the Czech vascular plants. Academia, Praha

Mogie M (1992) The evolution of asexual reproduction in plants. Chapman and Hall, London

Mráz P (2001) Chromosome numbers in selected species of Hieracium sect. Alpina from Central and Eastern Europe. Folia Geobot 36:321-332

Mráz P (2002) Contribution to the knowledge of the Hieracium rohacsense group in the Carpathians. Thaiszia J Bot 12:109-135

Mráz P (2003) Mentor effects in the genus Hieracium s. str. (Compositae, Lactuceae). Folia Geobot 38:345-350

Mráz P, Szeląg Z (2004) Chromosome numbers and reproductive systems in selected species of Hieracium and Pilosella (Asteraceae) from Romania. Ann Bot Fenn 41:405-414

Mráz P, Kovalčíková K, Marhold K (2002) Pollen shapes and size in Hieracium and related genera. In: Gutterman W (Ed) Contribution abstracts (lectures and posters) from 6th Hieracium Workshop, Hirschegg/Kleinwalsertal (Österreich), Institut für Botanik der Universität Wien, Wien, 27

Mráz P, Chrtek J, Fehrer J, Plačková I (2005) Rare recent natural hybridization in the genus Hieracium s.str.-evidence from morphology, allozymes and chloroplast DNA. Plant Syst Evol 255:177-192 
Murín A (1960) Substitution of cellophane for glass covers to facilitate preparation of permanent squashes and smears. Stain Technol 35:351-353

Murín A, Májovský J (1992) Karyological study of the Slovak Flora XXV. Acta Fac Rer Nat Univ Comenianae Bot 39:53-57

Nathan R (2006) Long-distance dispersal of plants. Science 313:786788

Otto F (1990) DAPI staining of fixed cells for high-resolution flow cytometry of nuclear DNA. In: Crissman HA, Darzynkiewicz Z (Eds) Methods in cell biology 33:105-110

Ozenda P (1985) La végétation de la chaîne alpine dans l'espace montagnard européen. Masson, Paris

Pawłowski B (1970) Remarques sur l'endémisme dans la flore des Alpes et des Carpates. Vegetatio 21:181-243

Ramsey J, Schemske DW (1998) Pathways, mechanisms, and rates of polyploid formation in flowering plants. Annu Rev Ecol Syst 29:467-501

Rich TCG, McDonnell EJ, Lledó MD (2008) Conservation of Britain's biodiversity: the case of Hieracium cyathis (Asteraceae) an its relation to other apomictic taxa. Bot J Linn Soc 156:669-680

Rosenberg O (1927) Die semiheterotypische Teilung und ihre Bedeutung für die Entstehung verdoppelter Chromosomenzahhlen. Hereditas (Lund) 8:305-338

R Development Core Team (ed) (2006) R: a language and environment for statistical computing. R Foundation for Statistical Computing, Vienna

Schmuths H, Meister A, Horres R, Bachman K (2004) Genome size variation among accessions of Arabidopsis thaliana. Ann Bot 93:317-321

Schönswetter P, Stehlik I, Holderegger R, Tribsch A (2005) Molecular evidence for glacial refugia of mountains plants in the European Alps. Mol Ecol 14:3547-3555

Schuhwerk F (1996) Published chromosome counts in Hieracium. http://www.botanik.biologie.uni-muenchen.de/botsamml/ projects/chrzlit.html

Schuhwerk F, Lippert W (1999) Chromosomenzahlen von Hieracium (Compositae, Lactuceae) Teil 3. Sendtnera 6:197-214
Skalińska M (1959) [Report on H. alpinum]. In: Skalińska M, Czapik $\mathrm{R}$, Piotrowicz $\mathrm{M}$ et al. (eds) Further studies in chromosome numbers of Polish Angiosperms (Dicotyledons). Acta Soc Bot Pol 28:523

Skawińska R (1963) Apomixis in Hieracium alpinum L. Acta Biol Cracov 5(1962):7-14

Slade K, Rich TCG (2007) Pollen studies in British Hieracium sect Alpina (Asteraceae). Watsonia 26:443-450

Sokolovskaya AP, Strelkova OS (1960) Geograficheskoe rasprostranenie poliploidnykh vidov v Evraziatskoï Arktike [Geographical distribution of polyploid species of plants in Eurasiatic Arctis]. Bot Zhurn 45:369-381

Stace CA, Gornall RJ, Squirrell J, Shi Y (1995) Chromosome numbers in Hieracium L. section Alpina (Fries) F. N. Williams. Watsonia 20:367-377

Štorchová H, Chrtek J Jr, Bartish IV, Tetera M, Kirschner J, Štěpánek J (2002) Genetic variation in agamospermous taxa of Hieracium sect Alpina (Compositae) in the Tatry Mts. (Slovakia). Plant Syst Evol 235:1-17

Suda J, Krahulcová A, Trávníček P, Rosenbaumová R, Peckert T, Krahulec F (2007) Genome size variation and species relationships in Hieracium subgenus Pilosella (Asteraceae) as inferred by flow cytometry. Ann Bot 100:1323-1335

Szeląg Z, Jankun A (1997) Tetraploid Hieracium alpinum in the Polish Tatra Mts. Fragm Florist Geobot 42:190-192

Temsch EM, Greilhuber J (2001) Genome size in Arachis duranensis: a critical study. Genome 44:826-830

Uhríková A, Murín A (1970) [Report on H. alpinum]. In: Májovský J et al., Index of chromosome numbers of Slovakian flora (Part 2). Acta Fac Rer Nat Univ Comenianae, Bot 18:53

Urbanska K (1991) Pollen and male function in agamospermous plants. Pol Bot Stud 2:71-84

Vandel A (1928) La parthénogenese geographique. Contribution à l'étude biologique et cytologique de la parthénogenese naturelle. Bull Biol Fr Belg 62:164-182

Vladimirov V (2000) Diploid species of the genus Hieracium s.l. in Bulgaria. Abh Ber Naturkundemus Görlitz 72, Suppl 16 